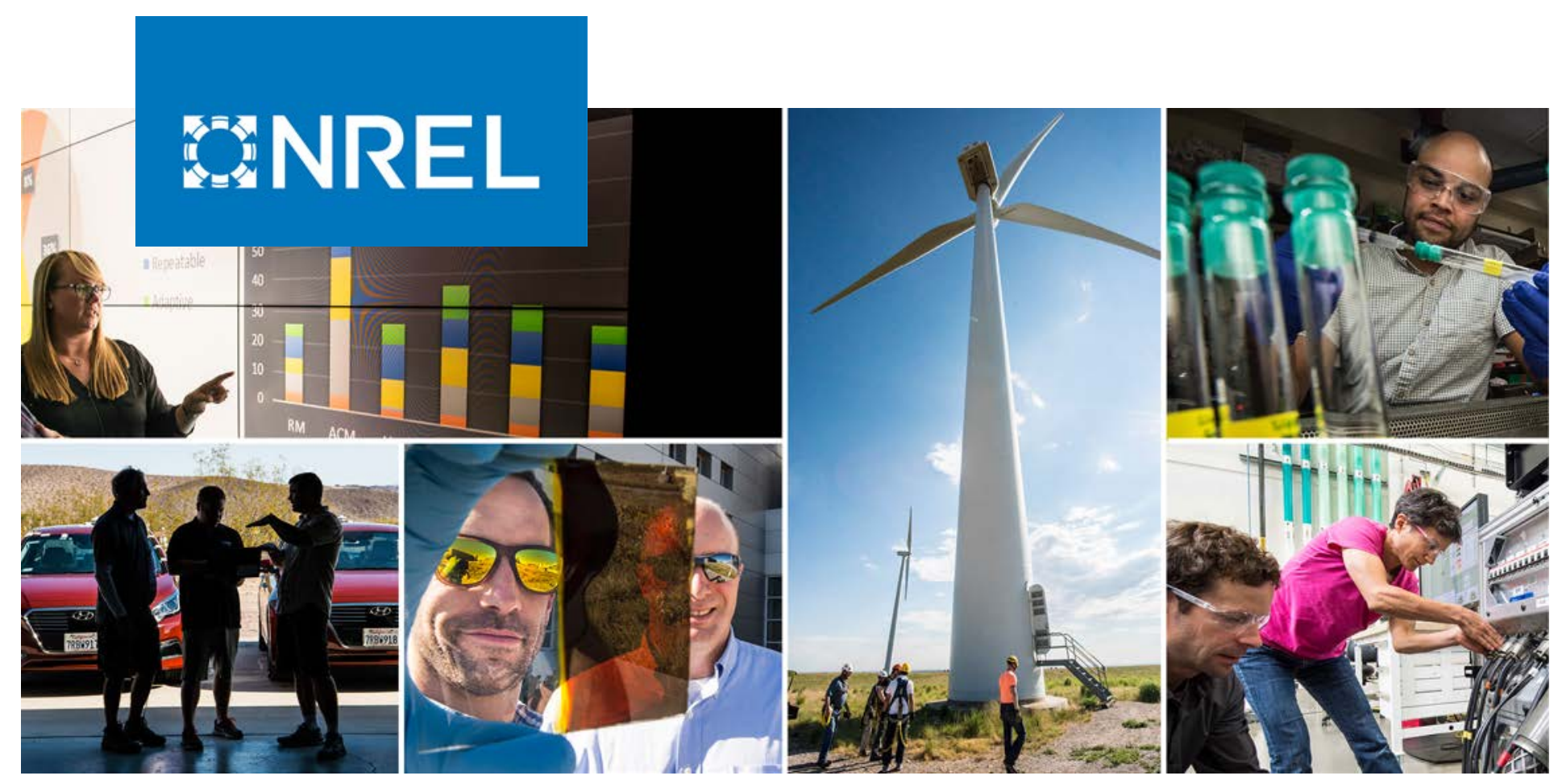

\title{
The Renewable Energy Potential (reV) Model: A Geospatial Platform for Technical Potential and Supply Curve Modeling
}

Galen Maclaurin, Nick Grue, Anthony Lopez, Donna Heimiller, Michael Rossol, Grant Buster, and Travis Williams

National Renewable Energy Laboratory

NREL is a national laboratory of the U.S. Department of Energy Office of Energy Efficiency \& Renewable Energy

Operated by the Alliance for Sustainable Energy, LLC

This report is available at no cost from the National Renewable Energy Laboratory (NREL) at www.nrel.gov/publications.
Technical Report

NREL/TP-6A20-73067

Revised June 2021 


\section{GNREL}

\section{The Renewable Energy Potential (reV) Model: A Geospatial Platform for Technical Potential and Supply Curve Modeling}

Galen Maclaurin, Nick Grue, Anthony Lopez, Donna Heimiller, Michael Rossol, Grant Buster, and Travis Williams

National Renewable Energy Laboratory

\section{Suggested Citation}

Maclaurin, Galen, Nick Grue, Anthony Lopez, Donna Heimiller, Michael Rossol, Grant Buster, and Travis Williams. 2019. The Renewable Energy Potential (reV) Model: A Geospatial Platform for Technical Potential and Supply Curve Modeling. Golden, CO: National Renewable Energy Laboratory. NREL/TP-6A20-73067.

https://www.nrel.gov/docs/fy19osti/73067.pdf.

NREL is a national laboratory of the U.S. Department of Energy Office of Energy Efficiency \& Renewable Energy Operated by the Alliance for Sustainable Energy, LLC

This report is available at no cost from the National Renewable Energy Laboratory (NREL) at www.nrel.gov/publications.

Contract No. DE-AC36-08GO28308
Technical Report NREL/TP-6A20-73067

Revised June 2021

National Renewable Energy Laboratory 15013 Denver West Parkway Golden, CO 80401 303-275-3000 • www.nrel.gov 


\section{NOTICE}

This work was authored by the National Renewable Energy Laboratory, operated by Alliance for Sustainable Energy, LLC, for the U.S. Department of Energy (DOE) under Contract No. DE-AC3608GO28308. Funding provided by U.S. Department of Energy Office of Energy Efficiency and Renewable Energy Wind and Water Technologies Office. The views expressed herein do not necessarily represent the views of the DOE or the U.S. Government.

This report is available at no cost from the National

Renewable Energy Laboratory (NREL) at

www.nrel.gov/publications.

U.S. Department of Energy (DOE) reports produced

after 1991 and a growing number of pre-1991

documents are available

free via www.OSTI.gov.

Cover Photos by Dennis Schroeder: (clockwise, left to right) NREL 51934, NREL 45897, NREL 42160, NREL 45891, NREL 48097, NREL 46526.

NREL prints on paper that contains recycled content. 


\section{Errata}

This report, originally published in September 2019, has been revised in June 2021 to include additional members of the project team as co-authors and acknowledge their contributions. 


\section{Acknowledgments}

This report was funded by the U.S. Department of Energy (DOE) Wind Energy Technologies Office (WETO). We thank Eric Lantz, Trieu Mai, and Greg Brinkman (National Renewable Energy Laboratory [NREL]) for their support of the Renewable Energy Potential (reV) model, since its inception and ongoing. We also thank Nate Blair, Dan Bilello, Doug Arent, Ricardo Oliveira, Ted Kwasnik, Dylan Hettinger, and Wesley Cole (NREL); as well as Patrick Gilman and Rich Tusing (DOE WETO). We acknowledge Billy Roberts (NREL), who created figures and maps for this publication. 


\section{List of Acronyms}

$\begin{array}{ll}\text { API } & \text { application programming interface } \\ \text { AEP } & \begin{array}{l}\text { annual energy production } \\ \text { capacity factor } \\ \text { CF }\end{array} \\ \text { CSP } & \text { concentrating solar power } \\ \text { DOE } & \text { U.S. Department of Energy } \\ \text { FESTIV } & \text { Flexible Energy Scheduling Tool for Integrating Variable Generation } \\ \text { LCOE } & \text { levelized cost of energy } \\ \text { NREL } & \text { National Renewable Energy Laboratory } \\ \text { NSRDB } & \text { National Solar Radiation Database } \\ \text { PD } & \text { power density } \\ \text { PV } & \text { photovoltaic } \\ \text { ReEDS } & \text { Regional Energy Deployment System } \\ \text { reV } & \text { Renewable Energy Potential } \\ \text { RPM } & \text { Resource Planning Model } \\ \text { SAM } & \text { System Advisor Model } \\ \text { WIND Toolkit } & \text { Wind Integration National Dataset Toolkit }\end{array}$




\section{Executive Summary}

The Renewable Energy Potential (reV) model is a platform for the detailed assessment of renewable energy resources and their geospatial intersection with grid infrastructure and land use characteristics. The reV model currently supports photovoltaic (PV), concentrating solar power (CSP), and land-based wind turbine technologies. Modules in the reV framework function at different spatial and temporal resolutions, allowing for the assessment of resource potential, technical potential, and supply curves at varying levels of detail. The platform runs on the National Renewable Energy Laboratory's (NREL's) high-performance computing system, providing scalable and efficient performance from a single location up to a continent, for a single year or decades of time-series resource data. Coupled with NREL's System Advisor Model (SAM), reV supports resource assessments from 5-minute to hourly temporal resolutions and supports the analysis of long-term (i.e., year-on-year) variability of renewable generation (e.g., interannual variability and exceedance probabilities).

Specific configurations of each technology (CSP, PV, or wind) can be varied across the analysis - e.g., a different wind turbine can be modeled at each location. The estimated generation and limitations put on developable land area — defined by the user-are used to calculate the technology-specific technical potential. For example, the user can limit the development by land ownership, terrain, land use/cover, urban areas, and custom inputs. Capital expenditures and operation-and-maintenance costs can also be specified by the user to represent current technologies or future cost scenarios for emerging technologies. The supply curve module is a spatial sorting algorithm based on plant siting, transmission cost, and regional competition, and it provides a geographically discrete estimate of the levelized cost of energy and supply (i.e., available resource capacity) for the renewable technologies modeled.

The reV model currently provides broad coverage across North America, South and Central Asia, South America, and South Africa to inform national- and international-scale analyses as well as regional infrastructure and deployment planning. Potential and intended users of reV model outputs include utility planners, regional and national agencies, project and land developers, internal NREL modelers, and external researchers. 


\section{Table of Contents}

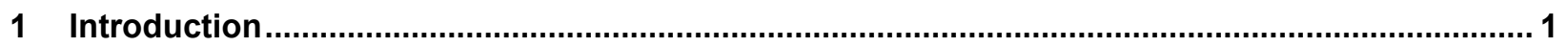

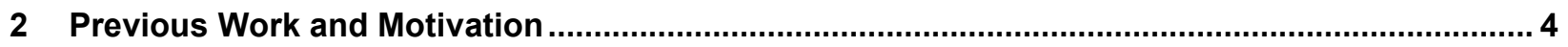

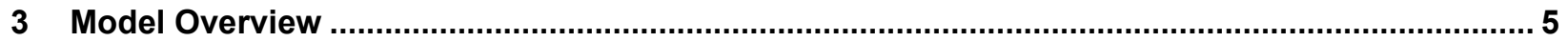

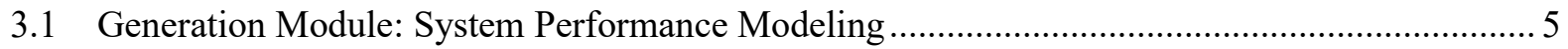

3.2 Site-Based Levelized Cost of Energy ................................................................................... 5

3.3 Spatial Exclusions Module: Technical and Sociopolitical Constraints on Land Availability....... 6

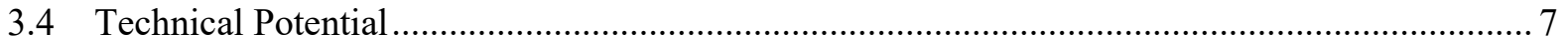

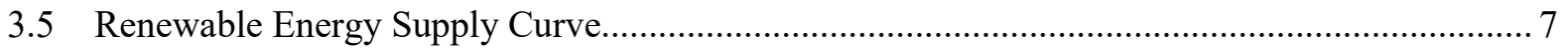

3.5.1 Aggregation from Continuous to Discrete Data Format .............................................. 7

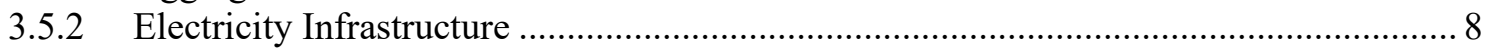

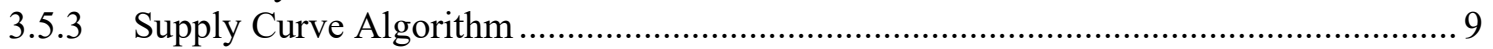

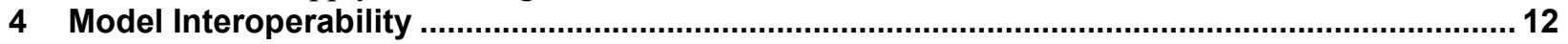

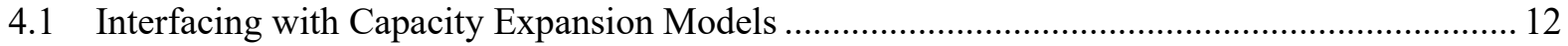

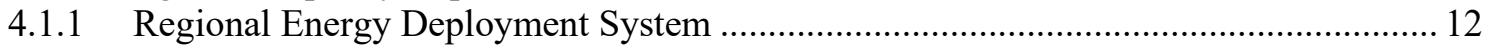

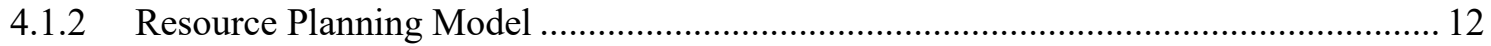

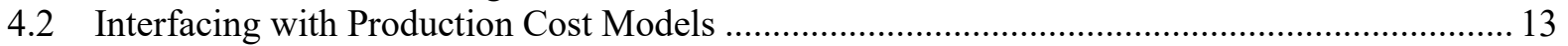

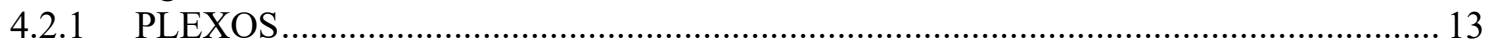

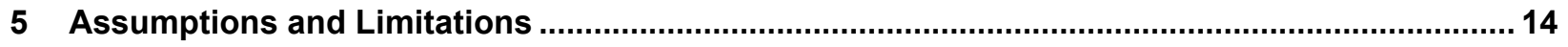

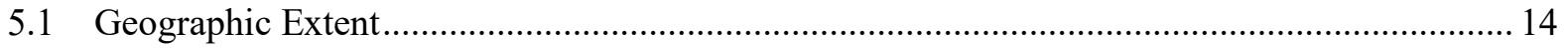

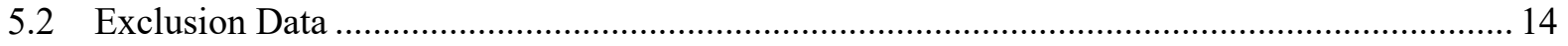

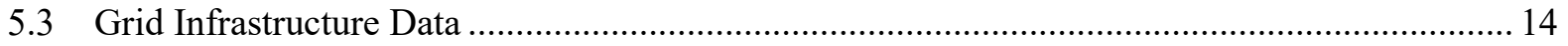

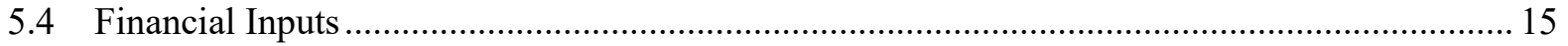

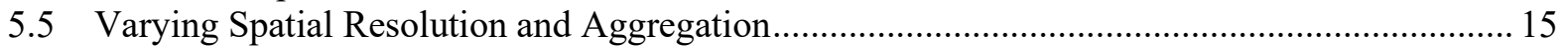

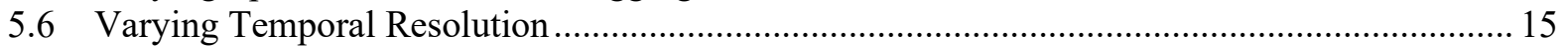

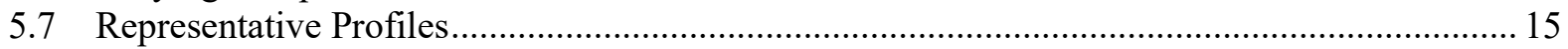

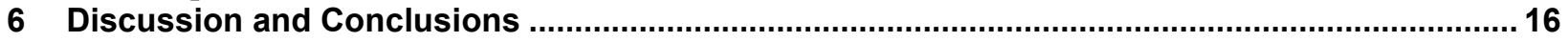

$7 \quad$ Future Work

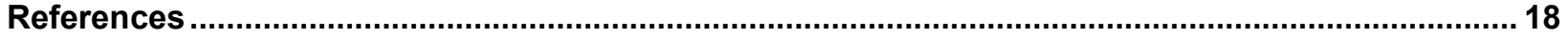

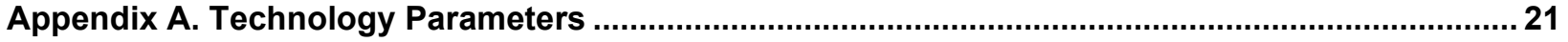

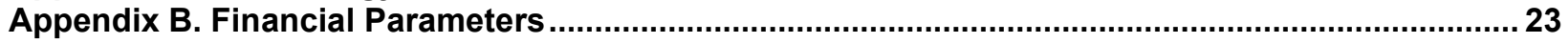

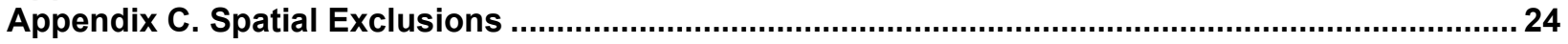

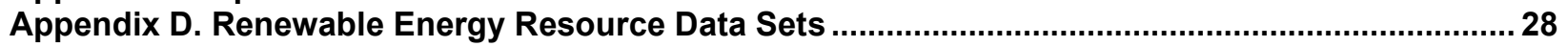




\section{List of Figures}

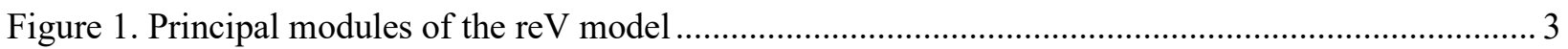

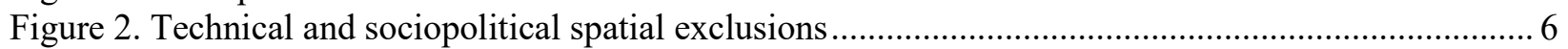

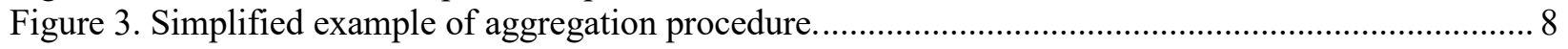

Figure 4. Example reV output maps and supply curve graph for land-based wind ................................. 11

Figure A-1. Land-Based Wind Turbine Power Curves................................................................. 21

\section{List of Tables}

Table A-1. Land-Based Wind Technology Parameters ........................................................................ 21

Table A-2. Utility-Scale Photovoltaic Technology Parameters (Urban and Rural) .................................. 21

Table A-3. Concentrating Solar Power Technology Parameters …..................................................... 22

Table B-1. Land-Based Wind Financial Parameters......................................................................... 23

Table B-2. Utility-Scale Photovoltaic Financial Parameters (Urban and Rural) ................................... 23

Table B-3. Concentrating Solar Power Financial Parameters............................................................ 23

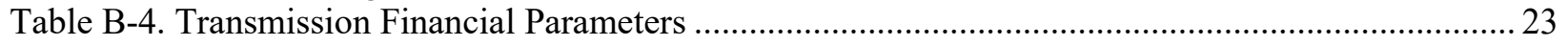

Table C-1. Land-Based Wind Spatial Exclusions............................................................................ 24

Table C-2. Utility-Scale Photovoltaic Spatial Exclusions Located in Rural Settings.............................. 26

Table C-3. Utility-Scale Photovoltaic Spatial Exclusions in Urban Settings .......................................... 27

Table C-4. Concentrating Solar Power Spatial Exclusions....................................................................... 27

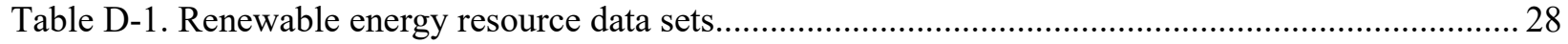




\section{Introduction}

There is increasing need in the renewable energy modeling community for a dynamic, flexible, and scalable framework that uses highly resolved spatial and temporal data to assess the potential energy supply and associated costs. The burgeoning availability of detailed time-series resource data (e.g., at hourly and even 5-minute time steps) and at fine spatial resolutions (e.g., between 1 $\mathrm{km}$ and $4 \mathrm{~km}$ ) has posed a challenge for the efficient estimation of technical potential and renewable energy supply curves at regional and national scales. The computational burden associated with these assessments has been a challenge for research in capacity expansion, production cost modeling, and optimization of site suitability and system configuration.

We present the Renewable Energy Potential (reV) ${ }^{1}$ model developed by the National Renewable Energy Laboratory (NREL) as a platform for the detailed assessment of solar and wind resources and their geospatial intersection with grid infrastructure and land use characteristics. reV dynamically models renewable generation, levelized cost of energy (LCOE), spatial exclusions on developable land, and the renewable energy supply curve. Currently supported renewable energy technologies include photovoltaic (PV), concentrating solar power (CSP), and land-based wind; other technologies could be integrated in the future. The model supports solar and wind resource data at varied spatial and temporal resolutions and allows the user to easily examine different spatial exclusions and multiple supply curve scenarios based on user-defined assumptions. The supply curve output and generation time-series profiles can be produced at multiple spatial resolutions. This flexibility facilitates a broad range of research agendas and efficient sensitivity analyses by varying input data sets; PV, CSP, and wind system configurations; and financial assumptions. The model is scalable from a single site to continental extents and can run on a single year or multiple years of resource data. In addition, the modular nature of reV creates an efficient workflow to produce input data for capacity expansion and production cost models.

reV was developed with a modular architecture so that all or parts of the pipeline can be executed and allows for custom inputs to any of the modules (Figure 1). The model is tightly coupled with NREL's System Advisor Model (SAM) ${ }^{2}$ (Gilman and Dobos 2012), which has become a leading software platform globally for estimating power generation and financial viability for renewable energy technologies. The reV model assesses resource potential from 5minute to hourly temporal resolutions and provides for the analysis of long-term (i.e., year-onyear) variability of renewable generation. Technical potential is a measure of resource potential (i.e., capacity) that could be developed based on assumptions of the developable land area defined by the user - in other words, how much renewable energy capacity could be developed in a given land area after accounting for land exclusions predefined by the user. For example, the user can limit development by land ownership, terrain, land use/cover, and urban areas, as well as custom inputs. Technology, transmission, and operation costs, based on the latest market data and future projections, are also embedded in the model. The supply curve module is a spatial sorting algorithm based on plant siting, transmission cost, and regional competition, and it

\footnotetext{
${ }^{1}$ The $\mathrm{V}$ in reV stands for electric potential.

2 https://sam.nrel.gov
} 
provides a geographically discrete estimate of LCOE and supply (i.e., capacity) for the specified technology. Additionally, model coupling modules are provided to interface with capacity expansion and production cost models (i.e., the Representative Profiles and Aggregated Profiles modules, respectively). Potential and intended users of the reV model outputs include utility planners, regional and national agencies, project and land developers, energy modelers, and researchers. 


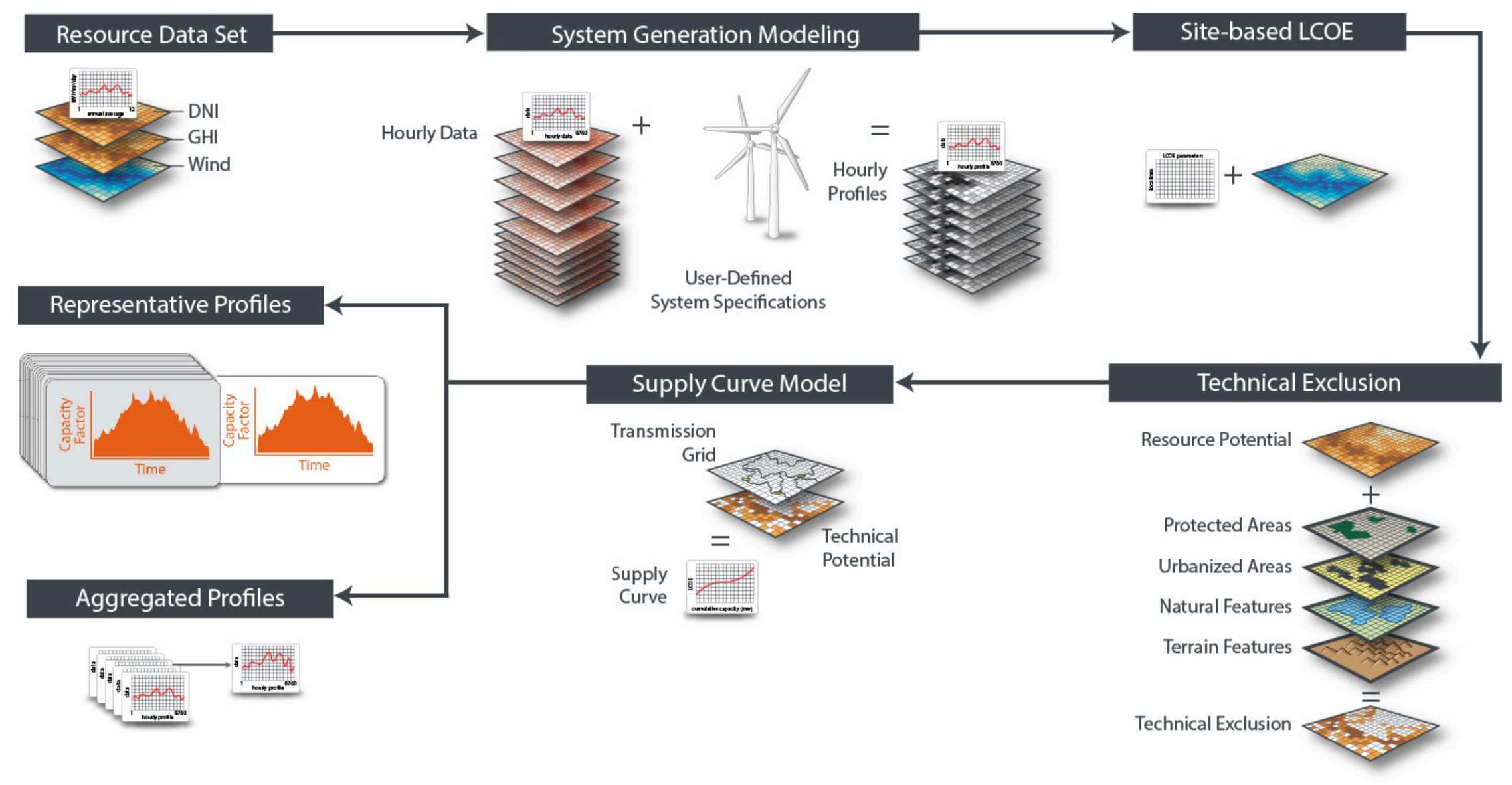

Figure 1. Principal modules of the reV model 


\section{Previous Work and Motivation}

Numerous studies and analyses have explored various aspects of renewable energy potential (Omitaomu et al. 2012; Rice et al. 2014; Huld 2017). The reV model, however, is internally motivated through the culmination of more than a decade of research and applied work at NREL (DOE 2008; Lopez et al. 2012; Doris, Lopez, and Beckley 2013; Barrows et al. 2015; Brown et al. 2016; Lopez et al. 2017). The initial motivation for reV was to integrate the disparate analysis frameworks used at NREL in the fields of resource modeling, technical potential, and renewable energy supply curves. The development of two state-of-the-art resource assessment data sets at NREL - the National Solar Radiation Database (NSRDB) (Sengupta et al. 2018) and the Wind Integration National Dataset (WIND) Toolkit (Draxl et al. 2015) — has broadened research in renewable energy supply curves, capacity expansion, and production cost modeling. The fine spatial and temporal resolutions of these data sets, however, increased the computational burden of representing resources in these models and required using subsets of the full data sets.

Although SAM provides an efficient application programming interface (API), the sheer size of the NSRDB (30-minute temporal and 4-km nominal spatial resolution) and the WIND Toolkit (hourly temporal and 2-km nominal spatial resolution) greatly limit the geographic scale at which estimates can be produced on a desktop system. Efficiently batching the SAM API across millions of resource locations (e.g., across the United States) and across multiple years of data requires a highly parallelized framework running on a cloud computing or high-performance computing system. The reV model overcomes these computational challenges while providing a highly flexible configuration module that allows for an individual renewable energy system configuration (e.g., site-specific wind turbine characteristics) at each resource location. reV also creates an automated processing pipeline between resource data sets and renewable energy supply curve, capacity expansion, and production cost modeling. 


\section{Model Overview}

The reV model has a modular, flexible structure that allows for a range of applications and can be interfaced with other modeling platforms. This design structure makes the model extensible, allowing for the addition of new renewable energy technologies and future development to address model assumptions, increase fidelity, and add new functionality. This section details the principal modules of reV, presented in Figure 1.

\subsection{Generation Module: System Performance Modeling}

The generation module is a complex wrapper that enables utility-scale system performance modeling using the SAM API with large spatiotemporal resource databases. System performance is estimated as a capacity factor: the percent of the manufacture's published nameplate capacity for a given system that is generated within a specific time period (e.g., across one hour or across an entire year). Capacity factors can be represented as gross (without system losses) or net (with systems losses). The annual capacity factor is multiplied by the system capacity to estimate the annual energy production (AEP) in megawatt-hours (MWh). Currently, reV can model userdefined parameters (e.g., wind hub height, PV inverter ratio) for PV, CSP, and land-based wind power plants. (See Appendix A for current technology parameters, system losses and assumptions used in reV.) The module is designed to read tens of terabytes of time-series solar or wind resource data in parallel and batches the SAM API across hundreds of workers (i.e., virtual or physical processing cores). The reV configuration module allows the user to model different renewable energy plant parameters at each resource location. Decision logic can be defined to assign plant parameters (e.g., wind turbine size, height, power curve, and more can be determined at each location based on the long-term mean wind speed), or the user can predetermine the plant parameters for each site.

\subsection{Site-Based Levelized Cost of Energy}

Levelized cost of electricity (LCOE) represents the average revenue per unit of electricity generated that would be required to recover the costs of building and operating a generating plant during an assumed financial life (EIA 2019). The LCOE module accepts the annual energy production (AEP) from the reV generation module. The resulting LCOE output can serve as the end point of a reV analysis, providing insight into economic competitiveness ( $\mathrm{Fu}$ et al.), relative performance competitiveness (Drury et al. 2014), and regional differences driven by cost assumptions. Alternatively, LCOE estimates can be used downstream in the supply curve algorithm (see Section 3.5). LCOE is currently estimated with the SAM API using the fixed charge rate method for wind and utility $\mathrm{PV}^{3}$ and the single-owner financial model for CSP. ${ }^{4}$ LCOE estimates are based on fixed assumptions - applied at all locations - of capital cost, operation-and-maintenance costs, and financing parameters for specific renewable energy technologies (see Section 5.4 for an explanation of cost multipliers as a way to vary costs regionally). Default financial parameters are from the Annual Technology Baseline ${ }^{5}$ but can be adjusted by users as needed. (See Appendix B for current financial parameters and assumptions.)

\footnotetext{
${ }^{3}$ https://sam.nrel.gov/financial-models/lcoe-calculator.html

${ }^{4}$ https://sam.nrel.gov/financial-models/utility-scale-ppa.html

5 https://www.nrel.gov/analysis/data-tech-baseline.html
} 
The modular framework of the reV model supports the future adoption of more detailed financial modeling driven by site-specific components of capital and operation-and-maintenance costs (e.g., breakdown of direct and indirect capital costs, detailed balance-of-station costs, state-level labor costs).

\subsection{Spatial Exclusions Module: Technical and Sociopolitical Constraints on Land Availability}

The spatial exclusions module is used to filter land area under specific scenarios to represent land access limitations experienced by renewable energy project developers (Figure 2). This is typically done to remove land areas from consideration that are deemed unavailable or undesirable for new development (Lopez et al. 2012). Exclusions can be broadly classified into three categories: technical barriers (e.g., water bodies, steep terrain), regulatory restrictions (e.g., federal, state, or local protected land; urban and suburban areas; protected wildlife species habitat), or stakeholder constraints (e.g., U.S. Forest Service lands, U.S. Department of Defense lands, private conservation areas). Spatial buffers can be applied around excluded areas to represent regulatory setbacks (e.g., many cities restrict utility wind development within $3 \mathrm{~km}$ of municipal boundaries). Exclusions are typically treated as hard limitations on developable land area; however, partial exclusions can be applied to represent uncertainty in the amount of land that can be developed within a specific land ownership class. For example, many U.S. Department of Defense lands can potentially be developed for wind energy but in limited amounts, and exact locations that are prohibited for development are classified. This uncertainty can be represented with partial exclusion (e.g., 50\%) that applies a percentage reduction on the available land area. Exclusions are evaluated at $90-\mathrm{m}$ spatial resolution to balance the level of detail of available land area estimates and computational efficiency. (See Appendix C for exclusions currently used in the reV model.)

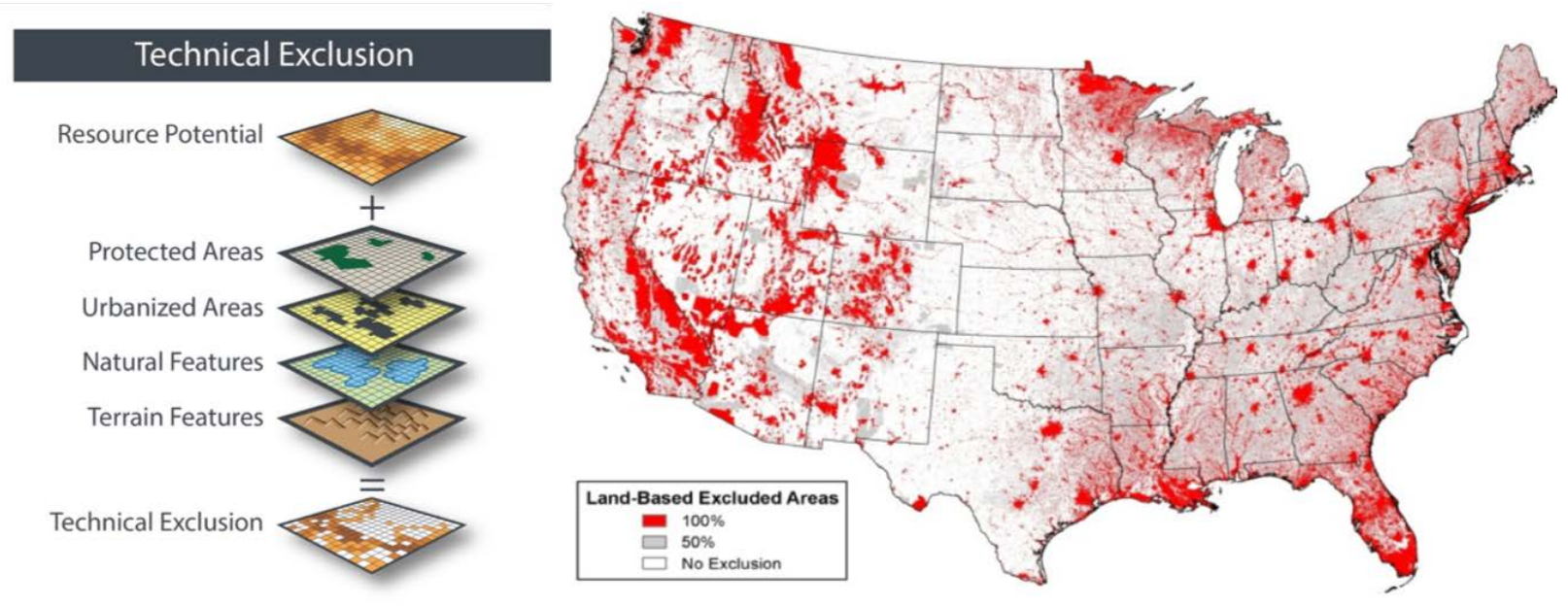

Figure 2. Technical and sociopolitical spatial exclusions 


\subsection{Technical Potential}

Technical potential is calculated as a function of the available land area after applying exclusions, the net capacity factor estimated by the generation module, and a user-defined power density appropriate for the specific technology. The power density value represents the maximum potential capacity for a given unit of area (e.g., $\mathrm{MW} / \mathrm{km}^{2}$ ):

\section{Annual technical potential $(M W h)=$ area $* P D * C F * 8760$}

where PD is the power density $\left(\mathrm{MW} / \mathrm{km}^{2}\right)$ and $\mathrm{CF}$ is the annual net capacity factor of the generator, as estimated in the generation module described in Section 3.1. The net capacity factors calculated in the generation module at the spatial resolution of the resource (e.g., $2 \mathrm{~km}$ or $4 \mathrm{~km}$ ) are mapped to the resolution of the exclusion module by nearest neighbor, and technical potential is computed at $90-\mathrm{m}$ spatial resolution.

\subsection{Renewable Energy Supply Curve}

A supply curve is a representation of the cost and amount of energy at all modeled potential sites at a snapshot in time (DOE 2015). The supply curve module applies a spatial optimization algorithm that sorts developable sites based on LCOE and accessibility to the transmission network. There are currently two options for estimating the supply curve: competitive connection and simple proximity. In the former, the lowest cost sites are examined first and assigned to electricity infrastructure features assuming a percentage availability of capacity on the transmission network (described in Section 3.6.1.1). When the capacity of the transmission features is not available in the spatial data for a study area (which is often the case for international studies), the simple proximity method can be applied based solely on the distance to the nearest grid feature. Unlike the competitive method, the simple proximity method does not compete potential plant locations against each other for connection to the grid. Either method estimates the total transmission interconnection cost for each site, based on a cost per kilometer (i.e., the spur line cost) and feature connection cost (e.g., line tie-in or substation).

\subsubsection{Aggregation from Continuous to Discrete Data Format}

The 90-m spatial resolution grid of underlying supply curve variables (e.g., LCOE, net capacity factors, available area, and associated capacity) results in data volumes that are too large (e.g., billions of pixels per variable) for many downstream applications, including the estimation of transmission costs. The first processing step of the supply curve module aggregates all input variables on the exhaustive $90-\mathrm{m}$ grid to discrete points in vector data format. This reduces the volume of data and produces a sparse spatial representation of the renewable energy potentiali.e., aggregated areas that are completely excluded for development are no longer stored. The aggregation step also allows for specific summarization related to resource quality that is required by some capacity expansion models. For example, NREL's Regional Energy Deployment System (ReEDS) model predicts future renewable energy expansion by resource class (i.e., bins of wind or solar resource quality) from the potential capacity at each supply curve location. ${ }^{6}$

${ }^{6}$ https://www.nrel.gov/analysis/reeds/ 
Variables on the 90-m grid can be aggregated using an aggregation factor to various resolutions, depending on the desired level of detail or data volume limitations of downstream models - e.g., for the contiguous United States, an aggregation factor of 64 is typically applied to the $90-\mathrm{m}$ grid, resulting in supply curve points that represent $33.2-\mathrm{km}^{2}$ areas. The developable area and associated potential capacity accounts for the spatial exclusions-i.e., the developable area is $33.2 \mathrm{~km}^{2}$, minus excluded areas (Figure 3). This aggregation allows for faster computation and an appropriate level of generalization for downstream models.

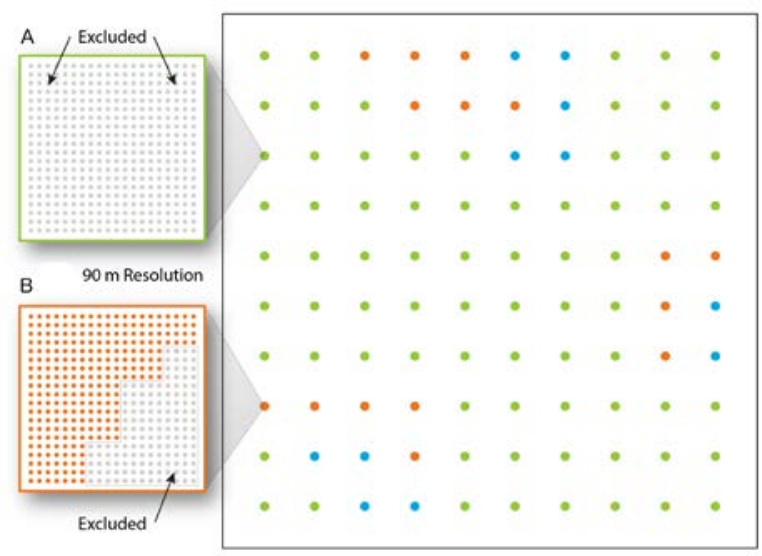

Figure 3. Simplified example of aggregation procedure.

An aggregation factor of 20 is shown, resulting in a maximum of $3.2 \mathrm{~km}^{2}$ represented by each supply curve point. Inset A shows a supply curve point that is completely excluded and thus will be removed in the sparse spatial representation. Inset B has $36 \%$ of the area excluded, resulting in $2.1 \mathrm{~km}^{2}$ of developable land. The different colors represent bins of resource quality (e.g., classes based on longterm mean wind speed).

\subsubsection{Electricity Infrastructure}

The supply curve algorithm uses four types of electricity infrastructure features: transmission lines, substations, load centers (typically represented by cities), and synthetic features that can be defined by the user or based on the specific modeling application. Each type of transmission feature has an associated cost of development based on distance to the feature (this is a static $\$ / \mathrm{km}$ cost) and the specific connection costs (e.g., tie-in or substation costs). (See Appendix B, Table 7, for all transmission financial assumptions.) The carrying capacity for each infrastructure feature is estimated and used in the supply curve allocation process. Typically, $10 \%$ of the capacity is considered available for the transfer of wind or solar power (DOE 2008), though this assumption can be adjusted by the user.

\subsubsection{Electricity Infrastructure Modeling Features}

- Transmission lines allow for resources to connect to the grid up to the carrying capacity of the individual line. When the capacity of the transmission line is unknown, line capacity is estimated based on its length and nominal voltage (Weiss and Spiewak 1998).

- Substations are linked to the transmission lines, marking their end points, and have a total capacity equal to the cumulative value of half of each connected transmission line's capacity. The carrying capacity is reduced when developable sites are connected to 
substations. When developable sites tie into a transmission line, the remaining capacities on the line and at the connected substations are reduced accordingly.

- Load centers for the United States, Canada, and Mexico are located in the center of cities with at least 10,000 people, with the remaining population represented by county at its spatial center. For other areas of focus, the threshold for the population is determined on a case-by-case basis. The city's capacity is represented using annual peak load (Ventyx 2013), apportioned to each city by population.

- Synthetic features are the centroids of balancing authority areas that absorb all the remaining capacity that cannot feasibly connect to the transmission grid. Sites that have too much capacity to connect to nearby transmission features or are too far from transmission features are forced to connect to these synthetic features. Developable sites connected to synthetic features quantify the potential capacity that is not supported by the existing transmission infrastructure, based on modeling assumptions.

\subsubsection{Tie-In Costs}

Different tie-in costs can be incurred depending on which transmission feature type is selected. In the competitive connection method, the costs of connecting to transmission lines, substations, load centers, or synthetic features are considered to minimize the total transmission interconnection cost. For the simple proximity method, the interconnection cost is calculated for the nearest grid feature.

- Connecting to a transmission line typically incurs an additional cost to reflect tying into the line, which requires installing a new substation.

- Connecting new resources to a substation generally would not require additional costs.

- Load centers presumably have infrastructure available to allow for the connection of new transmission lines.

- For modeling purposes, connection to synthetic features incur the same cost as tying directly into a transmission feature. This makes these features essentially a catchall for developable sites that cannot otherwise connect to grid infrastructure. The individual components of the transmission cost (spur line and tie-in) are provided in the supply curve output so that users can examine how much potential capacity connects to each type of feature.

\subsubsection{Supply Curve Algorithm}

The supply curve algorithm initially calculates the levelized cost of transmission-which includes spur-transmission and tie-in costs but not bulk transmission upgrade requirements-for all potential links from each developable site to nearby transmission features. Sites have a maximum connection distance based on their proximity to the nearest synthetic feature. In ReEDS, this is at most $383 \mathrm{~km}$ in the contiguous United States given the model's regional structure. The potential links are sorted by cost, and the site-to-infrastructure link with the lowest cost is selected. If the transmission feature's available capacity can accept the site capacity, then the site is connected. The transmission feature's available capacity is then decremented accordingly, and the algorithm continues to the next least-cost link. If the transmission feature's available capacity is insufficient to connect to the site, that potential link is discarded, and the next least-cost link is considered. 
The algorithm iteratively evaluates the least-cost potential links until all developable sites are connected. As the available capacity of transmission features decreases, sites are connected via longer, more expensive links. Sites that are unable to connect to a transmission line, substation, or load center because of a lack of available capacity are forced to connect to the synthetic feature, which acts as a catchall for capacity not connected to the transmission infrastructure. In practice, the algorithm can connect between 1.1 and $1.3 \mathrm{TW}$ of new capacity in the contiguous United States to transmission lines, substations, or load centers before insufficient capacity forces connection to synthetic features. Sites that connect to a synthetic feature reflect the technically available resource capacity that was not assigned an existing transmission feature. The supply curve can be summarized by sorting the LCOE and plotting it against the cumulative capacity (Figure 4). Moving up along the supply curve reflects lower quality resources and longer connection distances. 

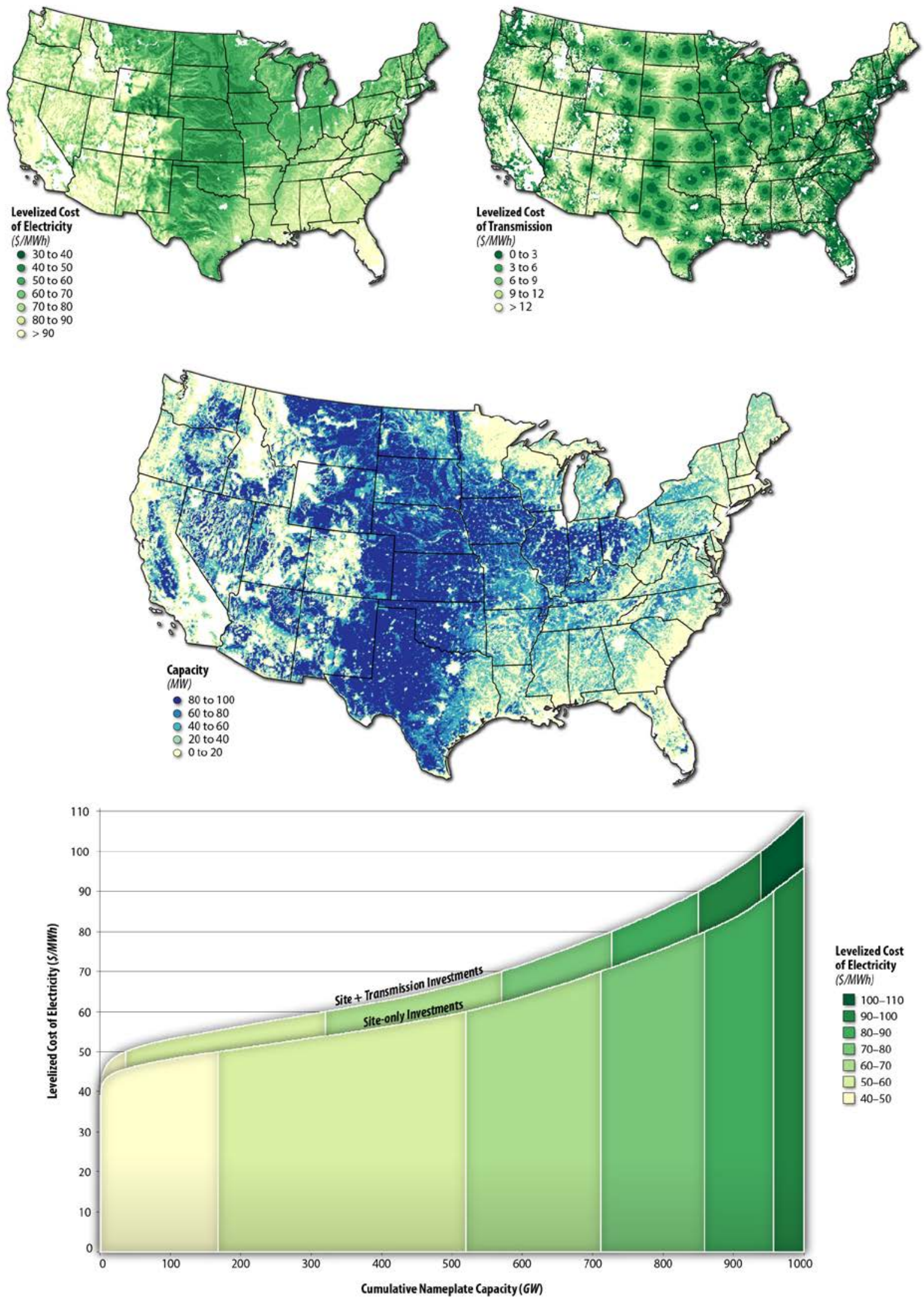

Figure 4. Example reV output maps and supply curve graph for land-based wind 


\section{Model Interoperability}

The reV model provides specific post-processing modules to couple with capacity expansion (Jadun et al. 2017) and production cost models (Hurlbut et al. 2016) used at NREL and by external collaborators (Chartan, Reber, and Brinkman 2018; Brancucci et al. 2018). Model interoperability modules are custom designed to interface with the specific needs of each downstream model.

\subsection{Interfacing with Capacity Expansion Models}

The reV model characterizes renewable energy resources over a large geographic extent and assists in optimizing the connection of those resources to the grid using financial inputs and calculating site-based LCOE and levelized cost of transmission. The supply curve module maps discreet areas of land that can be developed and connected to the grid ranked from lowest cost and nearest to the grid to highest cost and farthest from transmission features. The reV model provides the necessary inputs for capacity expansion models to determine which locations are most optimal for future renewable energy build-out.

\subsubsection{Regional Energy Deployment System}

ReEDS was developed at NREL to analyze scenario-based capacity expansion build-out projects of solar and wind resources (Cohen et al. 2019). The reV supply curve results feed into the ReEDS model to inform the decision of which resources to develop earlier or later in different build-out scenarios. The ranking of supply curve sites from least to most expensive is used to solve the ReEDS build-out optimization of which plots of land to develop into new solar and wind projects based on scenarios assumptions. The amount of generation profiles estimated by the reV model at each resource location results in orders of magnitude more data than can be used by ReEDS because of the complexity and computational burden of the capacity expansion solver. To reduce the data volume, representative profiles are selected for each build-out region to characterize the variability and magnitude of potential electricity generation for each renewable energy technology.

Representative profiles are selected based on a time stepwise mean of the generation time series within each ReEDS region. The time-series mean is also weighted based on the nonexcluded area represented by each resource profile. The representative profile is an actual profile that has been selected through minimizing the time stepwise difference from the weighted mean.

\subsubsection{Resource Planning Model}

The Resource Planning Model (RPM) ${ }^{7}$ was developed at NREL to evaluate capacity expansion at the regional level, such as utility service territory, state, or balancing authority (Mai et al. 2013; Barrows et al. 2015). RPM uses capacity factor time-series profiles from reV for regional clustering and estimation of electricity generation potential. The RPM model also makes use of area and capacity estimates of developable land from the exclusion module.

${ }^{7}$ https://www.nrel.gov/analysis/models-rpm.html 


\subsection{Interfacing with Production Cost Models}

The modeling pipeline behind national and continental grid integration studies involves reV, ReEDS, and production cost models, such as PLEXOS, developed by Energy Exemplar, ${ }^{8}$ or the Flexible Energy Scheduling Tool for Integrating Variable Generation (FESTIV), ${ }^{9}$ developed at NREL. Grid integration studies at NREL typically rely on supply curve outputs from reV, capacity expansion scenarios from the ReEDS model, and unit commitment and dispatch modeling using PLEXOS.

\subsubsection{PLEXOS}

After reV has characterized the renewable resources and optimized the connection of those resources to the grid, ReEDS determines the most optimal expansion of electricity infrastructure. At this point in the production cost modeling pipeline, renewable energy sites that ReEDS built through its optimization are identified in the supply curve along with their associated capacities and individual time-series power profiles. These are then aggregated (e.g., the sum of capacities and sum of power profiles) to the nearest PLEXOS node or geographic areas such as regional transmission organizations or other definitions of demand regions. The generation time series are then used within PLEXOS to model unit commitment and dispatch.

${ }^{8}$ https://www.nrel.gov/grid/power-market-design.html

${ }^{9}$ https://www.nrel.gov/grid/festiv-model.html 


\section{Assumptions and Limitations}

The reV model is an analysis platform for the relative assessment of renewable resources across broad geographic extents and provides a high-level perspective for site suitability assessment; however, the reV model cannot inform site-level characterization for renewable energy projects.

\subsection{Geographic Extent}

The reV model operates on large spatiotemporal resource data sets and characterizes renewable resource potential at regional, national, or continental scales. The drawback is that site-based constraints can be more difficult to represent, limited by the availability of detailed data. The reV model was designed to characterize the relative resource potential as influenced by modeled weather patterns, topographic landforms, land use and land cover, and proximity to existing electricity infrastructure. Localized, site-based, or city-level resource assessments require finer spatial resolution and higher fidelity underlying data than are available in the reV model. At such localized scales, the reV model can provide a simple estimate of resource potential, but higher fidelity tools and data would be needed for meaningful site-suitability analysis.

\subsection{Exclusion Data}

The reV model characterizes land availability across broad scales using spatial data from local organizations when available and relies on national or global data sources otherwise. This means that excluding land from development can depend on a particular data set that might or might not accurately represent the current state of development or land availability. The vintage of data can impact the analysis and must also be considered. Outdated data can potentially include or exclude areas of land that have been changed in more recent data sets. In addition, data sets that represent the social value of land is difficult to obtain compared to satellite-derived land cover data sets. Therefore, locations that appear viable for new solar or wind development might actually be off limits because of social factors. As more data become available that characterize the current state of land, reV analyses can be updated to factor in the latest and best-available spatial data.

\subsection{Grid Infrastructure Data}

The electricity transmission infrastructure is an incredibly complex and widespread interconnected system that must be simplified for modeling in reV. The availability of distributed transmission line data in a spatial format is limited, which means that we are often forced to consider only large-scale transmission lines to determine a developable site's proximity to nearby grid features. In addition, the transmission lines are further simplified to reduce the number of distinct transmission line features into a more generalized representation of transmission lines. Spatial transmission data tend to be regarded as sensitive or proprietary, which commonly restricts the level of detail or availability of these data for use in our analyses. For some study areas where transmission data are not available, we instead used production cost model nodes and connections, which are a very simplified representation of the transmission infrastructure. Although the reV model is flexible in the fidelity of the transmission data, the level of detail impacts the estimates of transmission costs. 


\subsection{Financial Inputs}

Financial parameters used within the reV model need to be simplified to account for the wide geographic extents across which the model operates. Capital costs, operating costs, fixed charge rates, transmission line construction costs, tie-in costs, and other financial parameters tend to be modeled at national scales. When available, multipliers can be used to account for regional variability in costs (e.g., labor rates, permitting costs, environmental mitigation). The validity of financial parameters and the underlying assumptions are a central concern in supply curve modeling. Studies conducted for countries with data limitations require researchers to approximate costs based on analogous analyses and make additional assumptions. For research conducted in the United States, financial parameters are sourced from the Annual Technology Baseline. Model results in these situations should therefore be interpreted in a relative sense to the cost inputs and not as a real-world evaluation of current costs.

\subsection{Varying Spatial Resolution and Aggregation}

Because of the wide variance in data being used within the model, we are forced to operate at no less than three different spatial resolutions: that of the resource data set, the spatial exclusion, and the aggregated supply curve. Resource data typically have a resolution between $1 \mathrm{~km}$ and 10 $\mathrm{m}$ for estimating AEP and LCOE. Spatial exclusions and technical potential are evaluated at 90$\mathrm{m}$ resolution to provide high-fidelity estimates of land availability and thus potential capacity, but not all the original exclusion data for a particular study might have been created at that resolution or finer. Finally, the amount of developable land at $90 \mathrm{~m}$ and the associated weighted average of resource potential are maintained as attributes in the supply curve aggregation; however, the spatial fidelity is greatly reduced in the supply curve outputs. Although this is not directly a limitation of the reV model, it is an important consideration for downstream models.

\subsection{Varying Temporal Resolution}

The reV model can run at various temporal resolutions, from 5-minute to hourly time steps. Temporal resolution can have a nontrivial impact on electricity generation estimates. Higher temporal resolution solar resource data better captures changing conditions of cloud cover and aerosols that are important factors in accurately estimating PV or CSP generation. High-temporal resolution wind resource data (e.g., 5-minute) is needed to realistically represent the variability of wind energy production, particularly for production cost modeling. When hourly wind resource data are the best available, accurate modeling of unit commitment and dispatch is limited.

\subsection{Representative Profiles}

Selecting a single representative profile from set of profiles is inherently forcing a generalization of the resource variability within a geographic extent. Loss of variability and mischaracterization of overall magnitude of the resource is a concern, as is the fact that the representative profile does not necessarily represent the most desirable sites from a developer's perspective.

Particularly for wind, the greater the diversity of topographic landforms, variability of terrain complexity, and different land cover types within the region, the less representative the selected profile will be. This relationship also scales with geographic extent-e.g., the selected profile at the state level will be less representative than at the county level. 


\section{Discussion and Conclusions}

The development of the reV model has significantly advanced the level of fidelity and complexity in national- and continental-scale modeling of wind and solar energy potential. The geospatial modeling platform has enabled researchers to dynamically examine renewable energy production and cost improvements, with high spatial and temporal fidelity, by modifying system and financial parameters, spatial exclusions, and transmission costs. Processing times for producing renewable energy supply curves and assessments of technology performance impacts have also been dramatically reduced. Although substantially improving our ability to understand how technological innovations and cost reductions could make renewable energy technologies more competitive and open new markets, the reV model has simultaneously illuminated new research directions to improve our underlying assumptions and increase the fidelity of broadscale supply curve modeling.

The reV model automates the entire supply curve modeling pipeline as well as downstream model coupling, and thus it limits human error to configuration of the model. Automation facilitates reproducibility of studies and enables sensitivity analyses of model assumptions. Once the initial effort of preparing the input data is completed for a new geographic extent, multiple model runs based on different assumptions are as simple as updating a configuration file and rerunning the model. The processing code was developed to run on NREL's high-performance computing infrastructure and could easily be ported to the cloud, expanding access and scalability of the platform. The model leverages distributed and parallel computing to efficiently process tens of terabytes of wind or solar resource data in a matter of minutes.

Model outputs were initially designed to support internal NREL modelers, U.S. Department of Energy (DOE) program managers, and other national laboratories regarding the overall, nationalscale potential for renewable energy technologies. The reV model has grown, however, to also inform a broader, international group of stakeholders, including the wind and solar industries (developers, owner/operators, original equipment manufacturers, consultancies); local, state, and national governments; policy decisionmakers; external researchers; as well as the general public. 


\section{Future Work}

The long-term vision of the reV project aims to more tightly couple meso- and microscale modeling efforts across NREL to more accurately estimate potential renewable energy production at individual sites across broad geographic scales. Supply curve modeling should move toward higher fidelity abstractions of reality and more critical examination of our modeling assumptions to inform solutions for present and future deployment barriers (e.g., wildlife impacts, social acceptance, site accessibility, and installation logistics). Technical and sociopolitical exclusions are currently modeled as binary limitations on the available area for wind and solar deployment; however, siting and permitting renewable energy projects is a local process that involves federal, state, and local governments and a boots-on-the-ground approach by developers. Regulatory barriers, original equipment manufacturers, technologies, and siting considerations are not static; they vary across space and time. Spatial exclusions should therefore be penalty- or cost-based rather than binary, loosening the assumption that development is prohibited in certain areas and providing a more real-world representation of the decisions faced by developers.

Higher fidelity representations of individual wind and solar energy plants (e.g., site-specific sizing and optimizing technology configurations) will more accurately model plant performance and financial viability and provide insight into potential improvements that emerging technologies can provide at the fleet-wide level (e.g., innovations in wake steering and advanced wind power plant controls, solar panel efficiency improvements, or variable generation plus storage).

Future work will develop spatially explicit development costs, site-specific technology characterization, and more detailed financial modeling as well as better capture the effects of colocation of technologies - currently, wind, PV, and CSP can occupy the same parcel of land. A pragmatic approach is being pursued to address modeling assumptions that are fixed across space (e.g., the power density of wind power plants in terms of potential capacity per square kilometer) and improvements to the transmission cost algorithm (e.g., moving beyond Euclidean distance for spur lines and addressing synthetic features as grid features). Incremental progress in these new areas of supply curve research will take a measured approach to ensure that improving one assumption does not exacerbate another. Offshore wind is currently being incorporated into the reV model, and other technologies will be considered and integrated based on research requirements. Finally, we intend to open source the Python code base in the near future. 


\section{References}

Barrows, C., T. Mai, E. Hale, A. Lopez, and K. Eurek. 2015. "Considering Renewables in Capacity Expansion Models: Capturing Flexibility with Hourly Dispatch." Proceedings of the 2015 IEEE Power and Energy Society General Meeting. Piscataway, NJ: Institute of Electrical and Electronics Engineers (IEEE). https://dx.doi.org/10.1109/PESGM.2015.7286578.

Brancucci, C., R. Bracho, G. Brinkman, and B. Hodge. 2018. Baja California Sur Renewable Integration Study (NREL/TP-5D00-72598). Golden, CO: National Renewable Energy Laboratory. https://www.nrel.gov/docs/fy19osti/72598.pdf.

Brown, A., P. Beiter, D. Heimiller, C. Davidson, P. Denholm, J. Melius, A. Lopez, D. Hettinger, D. Mulcahy, and G. Porro. 2016. Estimating Renewable Energy Economic Potential in the United States: Methodology and Initial Results (NREL/TP-6A20-64503). Golden, CO: National Renewable Energy Laboratory. https://www.nrel.gov/docs/fy15osti/64503.pdf.

Chartan, E., T. Reber, and G. Brinkman. 2018. "Preliminary Findings of the South Africa Power System Capacity Expansion and Operational Modelling Study: Preprint." Presented at the South African Wind Energy Association's WindAc Africa, Cape Town, South Africa, November 1415, 2017. https://www.nrel.gov/docs/fy18osti/70319.pdf.

Cohen, S., J. Becker, D. Bielen, M. Brown, W. Cole, K. Eurek, W. Frazier, B. Frew, P. Gagnon, J. Ho, P. Jadun, T. Mai, M. Mowers, C. Murphy, A. Reimers, J. Richards, N. Ryan, E. Spyrou, D. Steinberg, Y. Sun, N. Vincent, and M. Zwerling. 2019. Regional Energy Deployment System (ReEDS) Model Documentation: Version 2018 (NREL/TP-6A20-72023). Golden, CO: National Renewable Energy Laboratory. https://www.nrel.gov/docs/fy19osti/72023.pdf.

Doris, E., A. Lopez, and D. Beckley. 2013. Geospatial Analysis of Renewable Energy Technical Potential on Tribal Lands (DOE/IE-0013). Washington, D.C.: U.S. Department of Energy. https://www.nrel.gov/docs/fy13osti/56641.pdf.

Draxl, C., A. Clifton, B.-M. Hodge, and J. McCaa. 2015. "The Wind Integration National Dataset (WIND) Toolkit.” Applied Energy 151: 355-366.

Drury, E., A. Lopez, P. Denholm, and R. Margolis. 2014. "Relative Performance of Tracking versus Fixed Tilt Photovoltaic Systems in the USA." Progress in Photovoltaics: Research and Applications 22: 1302-1315. https://dx.doi.org/10.1002/pip.2373.

ESRI. 2016a. "USA Federal Lands." https://www.arcgis.com/home/item.html?id=8047eda3656e4241b75463a5451ba9e2.

ESRI. 2016b. "USA Landmarks." https://www.arcgis.com/home/item.html?id=6ffa5cb05c3b4978bd96b8a4b416ffa6.

ESRI. 2016c. "USA Parks." https://www.arcgis.com/home/item.html?id=578968f975774d3fab79fe56c8c90941. 
Freire, S., K. Macmanus, M. Pesaresi, E. Doxsey-Whitfield, and J. Mills. 2016. "Development of new open and free multi-temporal global population grids at $250 \mathrm{~m}$ resolution." Presented at AGILE.

Fu, R., T. L. James, D. Chung, D. Gagne, A. Lopez, and A. Dobos. 2015. "Economic Competitiveness of U.S. Utility-Scale Photovoltaics Systems in 2015: Regional Cost Modeling of Installed Cost (\$/W) and LCOE (\$/kWh)." Proceedings of the 2015 IEEE 42nd Photovoltaic Specialist Conference (PVSC). Piscataway, NJ: Institute of Electrical and Electronics Engineers (IEEE). https://dx.doi.org/10.1109/PVSC.2015.7356261.

Gilman, P. and A. Dobos. 2012. System Advisor Model (NREL/TP-6A20-53437). Golden, CO: National Renewable Energy Laboratory. https:/www.nrel.gov/docs/fy12osti/53437.pdf.

Huld, T. 2017. "PVMAPS: Software Tools and Data for Estimation of Solar Radiation and Photovoltaic Module Performance Over Large Geographic Areas.” Solar Energy 142: 171-181. https://doi.org/10.1016/j.solener.2016.12.014.

Hurlbut, D., S. Haase, C. Barrows, L. Bird, G. Brinkman, J. Cook, M. Day, V. Diakov, E. Hale, D. Keyser, A. Lopez, T. Mai, J. McLaren, E. Reiter, B. Stoll, T. Tian, H. Cutler, D. Bain, and T. Acker. 2016. Navajo Generating Station and Federal Resource Planning; Volume 1: Sectoral, Technical, and Economic Trends (NREL/TP-6A20-66506). Golden, CO: National Renewable Energy Laboratory. https://www.nrel.gov/docs/fy17osti/66506.pdf.

Jadun, P., C. McMillan, D. Steinberg, M. Muratori, L. Vimmerstedt, and T. Mai. 2017. Electrification Futures Study: End-Use Electric Technology Cost and Performance Projections through 2050 (NREL/TP-6A20-70485). Golden, CO: National Renewable Energy Laboratory. https://www.nrel.gov/docs/fy18osti/70485.pdf.

Jarvis, A., E. Guevara, H.I. Reuter, and A.D. Nelson. 2008. "Hole-Filled SRTM for the Globe: Version 4: Data Grid.” Presented at the CGIAR Consortium for Spatial Information.

Lopez, A., B. Roberts, D. Heimiller, N. Blair, and G. Porro. 2012. U.S. Renewable Energy Technical Potentials: A GIS-Based Analysis (NREL/TP-6A20-51946). Golden, CO: National Renewable Energy Laboratory. https://www.nrel.gov/docs/fy12osti/51946.pdf.

Lopez, A., G. Maclaurin, B. Roberts, and E. Rosenlieb. 2017. Capturing Inter-Annual Variability of PV Energy Production in South Asia (NREL/TP-6A20-68955). Golden, Co: National Renewable Energy Laboratory. https://www.nrel.gov/docs/fy17osti/68955.pdf.

Mai, T., E. Drury, K. Eurek, N. Bodington, A. Lopez, and A. Perry. 2013. Resource Planning Model: An Integrated Resource Planning and Dispatch Tool for Regional Electric Systems (NREL/TP-6A20- 56723). Golden, Co: National Renewable Energy Laboratory. https://www.nrel.gov/docs/fy13osti/56723.pdf.

National Conservation Easement Database. 2012. https:/www.conservationeasement.us/.

NAVTEQ. 2011. “Airport Boundaries.” 
Omitaomu, O. A., B. R. Blevins, W. C. Jochem, G. T. Mays, R. Belles, S. W. Hadley, T. J. Harrison, B. L. Bhaduri, B. S. Neish, and A. N. Rose. 2012. "Adapting a GIS-Based Multicriteria Decision Analysis Approach for Evaluating New Power Generating Sites." Applied Energy 96: 292-301. https://doi.org/10.1016/j.apenergy.2011.11.087.

Pesaresi, M., and S. Freire. 2016. "GHS Settlement Grid Following the REGIO Model 2014 in Application to GHSL Landsat and CIESIN GPW v4-multitemporal (1975-1990-2000-2015).” European Commission, Joint Research Center (JRC). http://data.europa.eu/89h/jrc-ghslghs smod pop globe r2016a.

Rice, J., M. Hejazi, L. Liu, J. Olson, P. Patel, C. Vernon, N. Voisin, and N. Zuljevic. 2014. "Insights from Coupling GCAM-USA with a High-Resolution Siting Model." Presented at the JGCRI Integrated Assessment Technical Workshop, October 20, 2014. http://www.globalchange.umd.edu/data/annual-meetings/2014/Rice_GCAMCERF\%20coupling GTSP.pdf.

Sengupta, M., Y. Xie, A. Lopez, A. Habte, G. Maclaurin, and J. Shelby. 2018. "The National Solar Radiation Database (NSRDB)." Renewable and Sustainable Energy Reviews 89: 51-60.

U.S. Department of Agriculture, U.S. Forest Service. 2019. "USFS Inventories Roadless Areas." http://data.fs.usda.gov/geodata/edw/datasets.php.

U.S. Department of Energy (DOE). 2008. 20\% Wind Energy by 2030: Increasing Wind Energy's Contribution to U.S. Electricity Supply (DOE/GO-102008-2567). Washington, D.C..

U.S. Department of Energy (DOE). 2015. Wind Vision: A New Era for Wind Power in the United States (Executive Summary, Full Report, and Appendices) (DOE/GO-102015-4557).

Washington, D.C. https://www.nrel.gov/docs/fy15osti/63197-2.pdf.

U.S. Department of the Interior, Bureau of Land Management. 2016. "BLM National Designated Areas of Critical Environmental Concern Polygons."

https://gis.blm.gov/EGISDownload/LayerPackages/BLM_National_ACEC.zip.

U.S. Geological Survey. 2014. U.S. Geological Survey, NLCD 2011 Land Cover (2011 Edition, amended 2014) - National Geospatial Data Asset (NGDA) Land Use Land Cover. Washington, D.C.

U.S. Geological Survey, Gap Analysis Program. 2016. Protected Areas Database of the United States (PAD-US), version 1.4 Combined Feature Class. Washington, D.C.

Ventyx. 2013. Energy Market Intelligence \& Forecasting Solutions. http://www.ventyx.com/velocity/energy-market-data.asp.

Weiss, L., and S. Spiewak. 1998. The Wheeling and Transmission Manual, Second Edition. United States: Prentice Hall. 


\section{Appendix A. Technology Parameters}

Table A-1. Land-Based Wind Technology Parameters

\begin{tabular}{lllll}
\hline Parameter & Unit & Class 1 & Class 2 & Class 3 \\
\hline Wind speed $(v)$ & Meters/second & $v>9$ & $8>v>9$ & $v<8$ \\
Power density & MW/km ${ }^{2}$ & 3 & 3 & 3 \\
Rated output & $\mathrm{kW}$ & 1,500 & 1,620 & 1,620 \\
Hub height & Meters & 80 & 80 & 80 \\
Rotor diameter & Meters & 77 & 82.5 & 100 \\
Total losses & Percentage & 16.7 & 16.7 & 16.7 \\
\hline
\end{tabular}

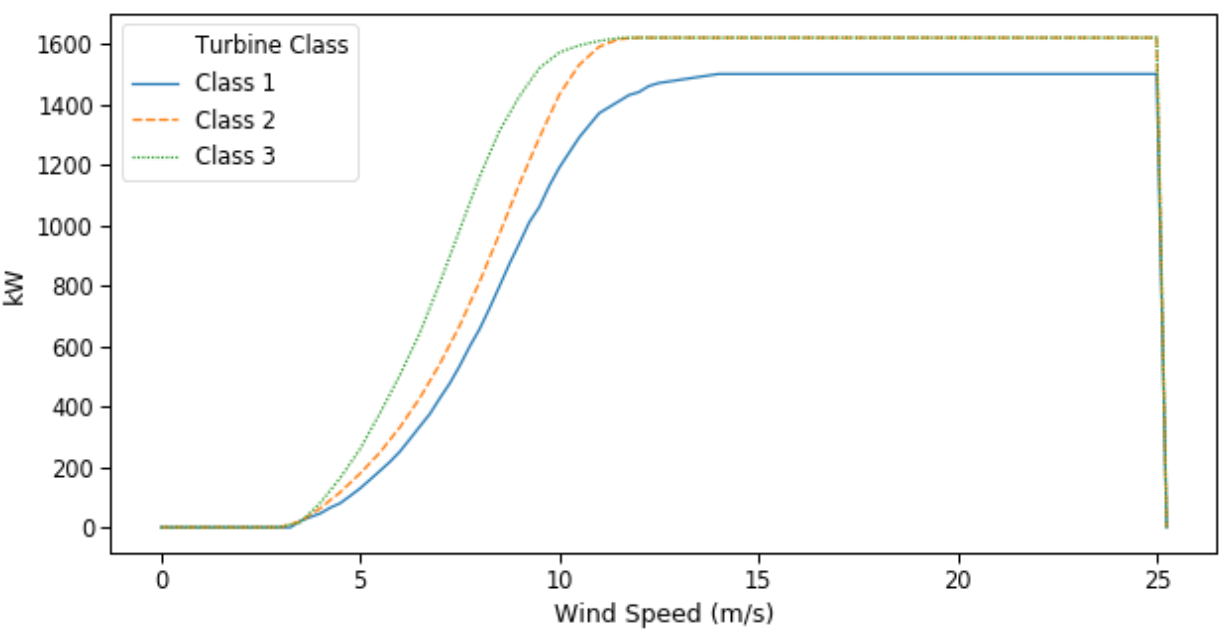

Figure A-1. Land-based wind turbine power curves

Table A-2. Utility-Scale Photovoltaic Technology Parameters (Urban and Rural)

\begin{tabular}{lll}
\hline Parameter & Unit & Utility-Scale PV \\
\hline Power density & MW/km2 & 32 \\
System capacity & $\mathrm{kW}$ & 20,000 \\
DC-to-AC ratio & Unitless & 1.3 \\
Inverter efficiency & Percentage & 96 \\
Array type & Categorical & 1 -axis tracking \\
Tilt & Degree & 0 \\
Azimuth & Degree & 180 \\
Losses & Percentage & 14.07566 \\
Module type & Categorical & Standard \\
Ground cover ratio & Unitless & 0.4 \\
\hline
\end{tabular}


Table A-3. Concentrating Solar Power Technology Parameters

\begin{tabular}{lll}
\hline Parameter & Unit & CSP \\
\hline Power density & MW/km2 & 14.9 \\
System capacity (nameplate) & MWe & 104 \\
System capacity (gross output) & MWe & 115 \\
Solar multiplier & Unitless & 1 \\
Receiver thermal power & MWt & 279 \\
Design-point DNI & W/m2 & 950 \\
Net conversion factor & Unitless & 0.9 \\
Cycle thermal efficiency & Unitless & 0.412 \\
Full-load hours of storage & Hours & 10 \\
Latitude of optical efficiency & Degrees & 38.3 \\
Total land area & 7.65 & $\mathrm{~km} 2$ \\
\hline
\end{tabular}




\section{Appendix B. Financial Parameters}

All financial parameters are based on a dollar year of 2015.

Table B-1. Land-Based Wind Financial Parameters

\begin{tabular}{lllll}
\hline Parameter & Unit & Class 1 & Class 2 & Class 3 \\
\hline Capital cost & $\$ / \mathrm{kW}$ & $\$ 1,492$ & $\$ 1,590$ & $\$ 1,840$ \\
Fixed operating cost & $\$ / \mathrm{kW}$-year & $\$ 51$ & $\$ 51$ & $\$ 51$ \\
Fixed charge rate & Unitless & 0.098 & 0.098 & 0.098 \\
\hline
\end{tabular}

Table B-2. Utility-Scale Photovoltaic Financial Parameters (Urban and Rural)

\begin{tabular}{lll}
\hline Parameter & Unit & Utility-Scale PV \\
\hline Capital cost & $\$ / k W$ & $\$ 1988$ \\
Fixed operating cost & $\$ / k W$-year & $\$ 13$ \\
Fixed charge rate & Unitless & 0.098 \\
\hline
\end{tabular}

Table B-3. Concentrating Solar Power Financial Parameters

\begin{tabular}{lll}
\hline Parameter & Unit & CSP \\
\hline Capital cost & $\$ / \mathrm{kW}$ & $\$ 6,507$ \\
Fixed operating cost & $\$ / \mathrm{kW}$-year & $\$ 66$ \\
Fixed charge rate & Unitless & 0.098 \\
\hline
\end{tabular}

Table B-4. Transmission Financial Parameters

\begin{tabular}{lll}
\hline Parameter & Unit & All Technologies \\
\hline Substation tie-in cost & $\$ / \mathrm{MW}$ & $\$ 0$ \\
Transmission tie-in cost & $\$ / \mathrm{MW}$ & $\$ 14,000$ \\
Transmission line cost & $\$ / \mathrm{MW}-\mathrm{km}$ & $\$ 3,667$ \\
\hline
\end{tabular}




\section{Appendix C. Spatial Exclusions}

Table C-1. Land-Based Wind Spatial Exclusions

\begin{tabular}{|c|c|c|c|c|}
\hline $\begin{array}{l}\text { Exclusion } \\
\text { Type }\end{array}$ & Source & Description & $\begin{array}{l}\text { Percentage } \\
\text { Exclusion }\end{array}$ & $\begin{array}{l}\text { Exclusion } \\
\text { Buffer }\end{array}$ \\
\hline Slope & $\begin{array}{l}\text { (Jarvis, } \\
\text { Guevara, } \\
\text { Reuter, and } \\
\text { Nelson 2008) }\end{array}$ & $\begin{array}{l}\text { Excludes lands with a slope greater } \\
\text { than } 20 \%\end{array}$ & 100 & N/A \\
\hline Urban areas & $\begin{array}{l}\text { (Pesaresi and } \\
\text { Freire 2016) }\end{array}$ & Suburban and urban areas & 100 & $3 \mathrm{~km}$ \\
\hline \multirow[t]{6}{*}{ Land use } & \multirow{6}{*}{$\begin{array}{l}\text { (U.S. } \\
\text { Geological } \\
\text { Survey 2014) }\end{array}$} & Open water & 100 & $300 \mathrm{~m}$ \\
\hline & & Woody wetlands & 100 & $300 \mathrm{~m}$ \\
\hline & & Emergent herbaceous wetlands & 100 & $300 \mathrm{~m}$ \\
\hline & & Deciduous forest & 50 & N/A \\
\hline & & Evergreen forest & 50 & $\mathrm{~N} / \mathrm{A}$ \\
\hline & & Mixed forest & 50 & N/A \\
\hline $\begin{array}{l}\text { U.S. Bureau } \\
\text { of Land } \\
\text { Management } \\
\text { Areas of } \\
\text { Critical } \\
\text { Environmental } \\
\text { Concern }\end{array}$ & $\begin{array}{l}\text { (U.S. } \\
\text { Department of } \\
\text { Interior, Bureau } \\
\text { of Land } \\
\text { Management } \\
\text { 2016) }\end{array}$ & $\begin{array}{l}\text { U.S. Bureau of Land Management } \\
\text { Areas of Critical Environmental } \\
\text { Concern }\end{array}$ & 100 & $3 \mathrm{~km}$ \\
\hline $\begin{array}{l}\text { Forest } \\
\text { Inventoried } \\
\text { Roadless } \\
\text { Area }\end{array}$ & $\begin{array}{l}\text { (U.S. Forest } \\
\text { Service 2019) }\end{array}$ & $\begin{array}{l}\text { U.S. National Forest Service } \\
\text { Inventoried Roadless Area }\end{array}$ & 100 & $3 \mathrm{~km}$ \\
\hline \multirow[t]{14}{*}{ Federal lands } & \multirow[t]{14}{*}{ (ESRI 2016a) } & National Battlefield & 100 & $3 \mathrm{~km}$ \\
\hline & & National Conservation Area & 100 & $3 \mathrm{~km}$ \\
\hline & & National Fish Hatchery & 100 & $3 \mathrm{~km}$ \\
\hline & & National Monument & 100 & $3 \mathrm{~km}$ \\
\hline & & National Park & 100 & $3 \mathrm{~km}$ \\
\hline & & National Recreation Area & 100 & $3 \mathrm{~km}$ \\
\hline & & National Scenic Area & 100 & $3 \mathrm{~km}$ \\
\hline & & National Wilderness Area & 100 & $3 \mathrm{~km}$ \\
\hline & & National Wildlife Refuge & 100 & $3 \mathrm{~km}$ \\
\hline & & Wild and Scenic River & 100 & $3 \mathrm{~km}$ \\
\hline & & Wildlife Management Area & 100 & $3 \mathrm{~km}$ \\
\hline & & National Forest & 50 & N/A \\
\hline & & National Grassland & 50 & N/A \\
\hline & & Air Force Guard & 50 & $\mathrm{~N} / \mathrm{A}$ \\
\hline
\end{tabular}




\begin{tabular}{|c|c|c|c|c|}
\hline & & Air Force & 50 & $\mathrm{~N} / \mathrm{A}$ \\
\hline & & Army & 50 & $\mathrm{~N} / \mathrm{A}$ \\
\hline & & Army Guard & 50 & $\mathrm{~N} / \mathrm{A}$ \\
\hline & & Coast Guard & 50 & $\mathrm{~N} / \mathrm{A}$ \\
\hline & & Marine Corps & 50 & $\mathrm{~N} / \mathrm{A}$ \\
\hline & & Navy & 50 & $\mathrm{~N} / \mathrm{A}$ \\
\hline Airports & $\begin{array}{l}\text { (NAVTEQ } \\
\text { 2011) }\end{array}$ & Airports & 100 & $3 \mathrm{~km}$ \\
\hline \multirow[t]{2}{*}{$\begin{array}{l}\text { Protected } \\
\text { Areas } \\
\text { Database- } \\
\text { U.S. }\end{array}$} & $\begin{array}{l}\text { (U.S. } \\
\text { Geological } \\
\text { Survey Gap } \\
\text { Analysis } \\
\text { Program 2016) }\end{array}$ & $\begin{array}{l}\text { An area having permanent protection } \\
\text { from conversion of natural land cover } \\
\text { and a mandated management plan in } \\
\text { operation to maintain a natural state } \\
\text { within which disturbance events (of } \\
\text { natural type, frequency, intensity, and } \\
\text { legacy) are allowed to proceed without } \\
\text { interference or are mimicked through } \\
\text { management }\end{array}$ & 100 & $3 \mathrm{~km}$ \\
\hline & & $\begin{array}{l}\text { An area having permanent protection } \\
\text { from conversion of natural land cover } \\
\text { and a mandated management plan in } \\
\text { operation to maintain a primarily natural } \\
\text { state but which might receive uses or } \\
\text { management practices that degrade } \\
\text { the quality of existing natural } \\
\text { communities, including suppression of } \\
\text { natural disturbances }\end{array}$ & 50 & $\mathrm{~N} / \mathrm{A}$ \\
\hline \multirow[t]{2}{*}{$\begin{array}{l}\text { National } \\
\text { Conservation } \\
\text { Easement } \\
\text { Database }\end{array}$} & $\begin{array}{l}\text { (National } \\
\text { Conservation } \\
\text { Easement } \\
\text { Database 2012) }\end{array}$ & $\begin{array}{l}\text { Managed for biodiversity-disturbance } \\
\text { events proceed or are mimicked }\end{array}$ & 100 & $3 \mathrm{~km}$ \\
\hline & & $\begin{array}{l}\text { Managed for biodiversity-disturbance } \\
\text { events are suppressed }\end{array}$ & 50 & $\mathrm{~N} / \mathrm{A}$ \\
\hline Ridges & $\begin{array}{l}\text { Modeled } \\
\text { (NREL) }\end{array}$ & $\begin{array}{l}\text { Identified ridge crest forests are given } \\
\text { full inclusion }\end{array}$ & 0 & $\mathrm{~N} / \mathrm{A}$ \\
\hline
\end{tabular}


Table C-2. Utility-Scale Photovoltaic Spatial Exclusions Located in Rural Settings

\begin{tabular}{|c|c|c|c|c|}
\hline Exclusion Type & Source & Description & $\begin{array}{l}\text { Percentage } \\
\text { Exclusion }\end{array}$ & $\begin{array}{l}\text { Exclusion } \\
\text { Buffer }\end{array}$ \\
\hline Slope & $\begin{array}{l}\text { (Jarvis et al. } \\
\text { 2008) }\end{array}$ & $\begin{array}{l}\text { Excludes lands with a } \\
\text { slope greater than } 5 \%\end{array}$ & 100 & $\mathrm{~N} / \mathrm{A}$ \\
\hline Urban areas & $\begin{array}{l}\text { (Pesaresi and } \\
\text { Freire 2016) }\end{array}$ & $\begin{array}{l}\text { Suburban and urban } \\
\text { areas }\end{array}$ & 100 & $\mathrm{~N} / \mathrm{A}$ \\
\hline Landmarks & (ESRI 2016b) & Landmarks & 100 & $\mathrm{~N} / \mathrm{A}$ \\
\hline Parks & (ESRI 2016c) & Parks & 100 & $\mathrm{~N} / \mathrm{A}$ \\
\hline \multirow[t]{3}{*}{ Land use } & \multirow{3}{*}{$\begin{array}{l}\text { (U.S. Geological } \\
\text { Survey 2014) }\end{array}$} & Open water & 100 & $\mathrm{~N} / \mathrm{A}$ \\
\hline & & Woody wetlands & 100 & $\mathrm{~N} / \mathrm{A}$ \\
\hline & & $\begin{array}{l}\text { Emergent herbaceous } \\
\text { wetlands }\end{array}$ & 100 & $\mathrm{~N} / \mathrm{A}$ \\
\hline $\begin{array}{l}\text { U.S. Bureau of } \\
\text { Land } \\
\text { Management } \\
\text { Areas of Critical } \\
\text { Environmental } \\
\text { Concern }\end{array}$ & $\begin{array}{l}\text { (U.S. Department } \\
\text { of Interior, Bureau } \\
\text { of Land } \\
\text { Management } \\
\text { 2016) }\end{array}$ & $\begin{array}{l}\text { U.S. Bureau of Land } \\
\text { Management Areas of } \\
\text { Critical Environmental } \\
\text { Concern }\end{array}$ & 100 & $N / A$ \\
\hline $\begin{array}{l}\text { U.S. National } \\
\text { Forest Inventoried } \\
\text { Roadless Area }\end{array}$ & $\begin{array}{l}\text { (U.S. Forest } \\
\text { Service 2019) }\end{array}$ & $\begin{array}{l}\text { U.S. National Forest } \\
\text { Service Inventoried } \\
\text { Roadless Area }\end{array}$ & 100 & $\mathrm{~N} / \mathrm{A}$ \\
\hline \multirow[t]{11}{*}{ Federal lands } & (ESRI 2016a) & National Battlefield & 100 & $N / A$ \\
\hline & & $\begin{array}{l}\text { National Conservation } \\
\text { Area }\end{array}$ & 100 & $N / A$ \\
\hline & & National Fish Hatchery & 100 & $\mathrm{~N} / \mathrm{A}$ \\
\hline & & National Monument & 100 & $N / A$ \\
\hline & & National Park & 100 & $\mathrm{~N} / \mathrm{A}$ \\
\hline & & $\begin{array}{l}\text { National Recreation } \\
\text { Area }\end{array}$ & 100 & $N / A$ \\
\hline & & National Scenic Area & 100 & $N / A$ \\
\hline & & $\begin{array}{l}\text { National Wilderness } \\
\text { Area }\end{array}$ & 100 & $\mathrm{~N} / \mathrm{A}$ \\
\hline & & $\begin{array}{l}\text { National Wildlife } \\
\text { Refuge }\end{array}$ & 100 & $N / A$ \\
\hline & & Wild and Scenic River & 100 & $N / A$ \\
\hline & & $\begin{array}{l}\text { Wildlife Management } \\
\text { Area }\end{array}$ & 100 & $N / A$ \\
\hline
\end{tabular}


Table C-3. Utility-Scale Photovoltaic Spatial Exclusions in Urban Settings

\begin{tabular}{|c|c|c|c|c|}
\hline Exclusion Type & Source & Description & $\begin{array}{l}\text { Percentage } \\
\text { Exclusion }\end{array}$ & $\begin{array}{l}\text { Exclusion } \\
\text { Buffer }\end{array}$ \\
\hline Slope & (Jarvis et al. 2008) & $\begin{array}{l}\text { Excludes lands with } \\
\text { a slope greater than } \\
5 \%\end{array}$ & 100 & $\mathrm{~N} / \mathrm{A}$ \\
\hline Urban areas & $\begin{array}{l}\text { (Pesaresi and } \\
\text { Freire 2016) }\end{array}$ & $\begin{array}{l}\text { Areas outside of } \\
\text { urban boundaries } \\
\text { were excluded }\end{array}$ & 100 & $\mathrm{~N} / \mathrm{A}$ \\
\hline Urban built-up & (Freire et al. 2016) & $\begin{array}{l}\text { Areas within urban } \\
\text { boundaries with } \\
>50 \% \text { built were } \\
\text { excluded }\end{array}$ & 100 & $\mathrm{~N} / \mathrm{A}$ \\
\hline Landmarks & (ESRI 2016b) & Landmarks & 100 & $\mathrm{~N} / \mathrm{A}$ \\
\hline Parks & (ESRI 2016c) & Parks & 100 & $\mathrm{~N} / \mathrm{A}$ \\
\hline \multirow[t]{6}{*}{ Land use } & \multirow{6}{*}{$\begin{array}{l}\text { (U.S. Geological } \\
\text { Survey 2014) }\end{array}$} & Open water & 100 & $\mathrm{~N} / \mathrm{A}$ \\
\hline & & Deciduous forest & 100 & $N / A$ \\
\hline & & Evergreen forest & 100 & $\mathrm{~N} / \mathrm{A}$ \\
\hline & & Mixed forest & 100 & $N / A$ \\
\hline & & Woody wetlands & 100 & $\mathrm{~N} / \mathrm{A}$ \\
\hline & & $\begin{array}{l}\text { Emergent } \\
\text { herbaceous } \\
\text { wetlands }\end{array}$ & 100 & $\mathrm{~N} / \mathrm{A}$ \\
\hline
\end{tabular}

Table C-4. Concentrating Solar Power Spatial Exclusions

\begin{tabular}{lllll}
\hline $\begin{array}{l}\text { Exclusion } \\
\text { Type }\end{array}$ & Source & Description & $\begin{array}{l}\text { Percent } \\
\text { Exclusion }\end{array}$ & $\begin{array}{l}\text { Exclusion } \\
\text { Buffer }\end{array}$ \\
\hline Slope & $\begin{array}{l}\text { (Jarvis et al. } \\
2008)\end{array}$ & $\begin{array}{l}\text { Excludes lands with a slope greater than } \\
3 \%\end{array}$ & 100 & $\mathrm{~N} / \mathrm{A}$ \\
$\begin{array}{l}\text { Contiguous } \\
\text { area }\end{array}$ & Modeled & $\begin{array}{l}\text { Excluded parcels of land that did not } \\
\text { amount to at least } 5 \mathrm{~km}^{2} \text { of contiguous } \\
\text { area }\end{array}$ & 100 & $\mathrm{~N} / \mathrm{A}$
\end{tabular}

All other spatial exclusions mirror those used for the land-based wind technology, located in Appendix C, Table 8. 


\section{Appendix D. Renewable Energy Resource Data Sets}

Table D-1. Renewable energy resource data sets.

\begin{tabular}{llllll}
\hline Resource Data Set & $\begin{array}{l}\text { Geographic } \\
\text { Extent }\end{array}$ & $\begin{array}{l}\text { Spatial } \\
\text { Resolution }\end{array}$ & $\begin{array}{l}\text { Temporal } \\
\text { Resolution }\end{array}$ & $\begin{array}{l}\text { Temporal } \\
\text { Range }\end{array}$ & Source \\
\hline $\begin{array}{l}\text { National Solar Radiation } \\
\text { Database (Physical Solar } \\
\text { Model) }\end{array}$ & $\begin{array}{l}\text { Western } \\
\text { Hemisphere } \\
\text { (land only) }\end{array}$ & $\begin{array}{l}\text { Nominal } \\
4 \times 4 \mathrm{~km}\end{array}$ & Half-hourly & $1998-2017$ & NREL \\
$\begin{array}{l}\text { National Solar Radiation } \\
\text { Database (South Asia) }\end{array}$ & South Asia & $\begin{array}{l}\text { Nominal } \\
10 \times 10 \mathrm{~km}\end{array}$ & Hourly & $2000-2014$ & $\mathrm{NREL}$ \\
$\begin{array}{l}\text { Wind Integration National } \\
\text { Dataset Toolkit }\end{array}$ & $\begin{array}{l}\text { North } \\
\text { America }\end{array}$ & $\begin{array}{l}\text { Nominal } \\
2 \times 2 \mathrm{~km}\end{array}$ & 5 -minute & $2007-2013$ & $\mathrm{NREL}$ \\
\hline
\end{tabular}

